Research Article

\title{
Hubungan Adversity Quotient dan Hasil Belajar Matematika Peserta Didik dalam Pembelajaran Jarak Jauh di SMP
}

Nurul Laili ${ }^{1}$

\section{${ }^{1}$ Pendidikan Matematika, Sekolah Pasca Sarjana Universitas Muhammadiyah PROF. DR. HAMKA. Jakarta, Indonesia.}

\section{Article History \\ Received: \\ 01.03 .2021}

Revised:

11.04.2021

Accepted:

13.04.2021

*Corresponding Author:

Nurul Laili

Email:

nurullaili1009@gmail.com

This is an open access article, licensed under: $\mathrm{CC}-\mathrm{BY}-\mathrm{SA}$
Abstract: Masa pandemi ini sangat mempengaruhi perkembangan siswa dalam melaksanakan kegiatan pembelajaran sehingga harus melakukan pembelajaran jarak jauh. Siswa dikatakan berhasil mengikuti pembelajaran dengan baik dengan melihat hasil belajarnya. Adversity Quotient merupakan salah satu kecerdasan yang dimiliki untuk mengenali kesulitan diri sendiri dan mampu mengubahnya sebagai potensi untuk mengatasi kesulitan. Hal ini penting dilakukan mahasiswa dalam kegiatan pembelajaran jarak jauh kali ini. Penelitian ini bertujuan untuk mengetahui hubungan antara Adversity Quotient dengan hasil belajar matematika. Subjek dalam penelitian ini adalah siswa kelas VII di Depok. Metode penelitian yang digunakan adalah survei dengan analisis data deskriptif. Pengumpulan data menggunakan media Google Form dengan menyebarkan kuesioner yang berjumlah 16 item pernyataan. Responden dalam penelitian ini berjumlah 130 siswa, dengan 61 siswa laki-laki dan 69 siswa perempuan. Hasil yang diperoleh dalam uji korelasi penelitian ini memiliki nilai sig. 0,000 $<0,05$. Dapat disimpulkan bahwa terdapat hubungan yang signifikan dan positif antara Adversity Quotient dengan hasil belajar siswa.

Kata Kunci: Adversity Quotient, Hasil Belajar Matematika, PJJ.

Relationship between Adversity Quotient and Students' Mathematics Learning Outcomes for Distance Learning in Junior High Schools

Abstract: This pandemic period greatly affects the development of students in carrying out learning activities so they have to do distance learning. Students are said to be successful in following the learning well by seeing the learning outcomes. Adversity Quotient is one of the intelligences possessed to recognize one's own difficulties and be able to change them as potential to overcome difficulties. This is important for students in distance learning activities at this time. This study aims to determine the relationship between Adversity Quotient and mathematics learning outcomes. The subjects in this study were 7th grade students in Depok. The research method used was a survey with descriptive data analysis. Collecting data using Google Form media by distributing questionnaires with a total of 16 statement items. Respondents in this study were 130 students, with 61 male students and 69 female students. The results obtained in the correlation test of this study have a sig value. $0.000<0.05$. It can be concluded that there is a significant and positive relationship between Adversity Quotient and student learning outcomes.

Keywords: Adversity Quotient, Distance Learning, Mathematics Learning Outcomes. 


\section{Pendahuluan}

Suatu negara penting untuk membangun warganya sebagai SDM melalui Pendidikan. Segala penderitaan rakyat berupa ketertinggalan dapat diatasi dengan upaya manusia untuk mengembangkan kemampuan dan mengarahkannya untuk menjadi manusia yang yang berpotensi dalam kehidupan bertahan hidup dan terus maju seiring dengan perkembangan zaman. Menurut hasil PISA yang digagas oleh OECD pada tahun 2018 menunjukan Indonesia ada di posisi ke-73 dari total 79 negara dengan perolehan rata-rata dunia 386, skor tersebut lebih rendah dari skor rata-rata dari OECD yaitu 489 [1]. Hal ini mengartikan posisi Indonesia berada di tingkat bawah dan belum menunjukan perubahan positif yang signifikan. Hal tersebut disebabkan karena banyak peserta didik masih mengalami kesulitan dalam pembelajaran dan belum mengenali kelemahan yang menyebabkan kesulitan tersebut yang nantinya bisa disadari sebagai potensi diri yang kuat, kemudian bisa dikembangkan sehingga kesulitan tersebut bisa diatasi. Tentunya hal ini didukung oleh pelaksana Pendidikan, untuk menyelidiki penyebab kesulitan peserta didik sehingga bisa diolah kemudian dikembangkan sebagai hal positif dan membangun.

Pendidikan merupakan proses keseimbangan untuk mengembangkan potensi individu dilihat dari berbagai aspek yaitu emosional, fisik, intelektual, spiritual dan social [2]. Berdasarkan uraian tersebut dan sesuai dengan UU mengenai fungsi dan tujuan Pendidikan sebagai sarana sosialisasi untuk membentuk mengembangkan kemampuan peserta didik sebagai generasi bangsa yang bersifat membangun, aktif, berkarakter, berintelektual tinggi, dan berpotensi positif untuk memajukan bangsa. Hidayah, dkk menyatakan meskipun sampai saat ini pelajaran matematika di jenjang sekolah menengah dengan jam pelajaran yang cukup banyak, realita menunjukkan bahwa mayoritas peserta didik yang belum memenuhi target yang sesuai berdasarkan tujuan pendidikan nasional [3]. Dengan demikian diperlukannya upaya pengenalan dan penggalian potensi diri peserta didik untuk diteliti sebagai penemuan baru yang bisa diterapkan adalah salah satu faktor penyempurna untuk menciptakan peserta didik menjadi generasi hebat.

Pendidikan harus direncanakan sesuai dengan pengembangan kompetensi peserta didik dalam literatur dan proses berpikir [4]. Lembaga pendidikan menginterpretasikan proses pembelajaran dalam bentuk hasil belajar. Hasil belajar berupa penilaian mengukur pengetahuan, keterampilan dan kemampuan dalam program pendidikan [5]. Melalui hasil belajar tersebut pendidik dapat mengukur sejauh mana keberhasilan siswa dalam pencapaiannya pada proses pembelajaran, hasil ini dapat menjadi evaluasi untuk meningkatkan kembali kemampuan peserta didik yang belum tercapai.

Matematika adalah suatu ilmu yang paling dasar dan berperan penting dalam berjalannya perkembangan pengetahuan dan kemajuan teknologi [6]. Sebagai dasar dari ilmu sains dan teknologi, peserta didik dituntut untuk mempunyai kemampuan dalam menyelesaikan permasalahan matematika. Kesiapan peserta didik dalam menghadapi permasalahan matematis ini akan berpengaruh pada penilaian hasil belajar di sekolahnya. Peserta didik mempunyai persepsi yang berbeda apabila dihadapkan oleh suatu masalah, sebagian dari mereka menganggap suatu masalah bisa diatasi secara matematis meskipun mereka mempunyai kekurangan dan sebagian yang lain memilih untuk menyerah sebelum menggali potensi diri. Hal ini disebut dengan Adversity Quotient.

Adversity Quotient berasal dari pertengahan tahun 1990-an yang diusulkan oleh seorang sarjana Amerika terkenal dan pelatih professional bernama Paul Stoltz [7]. Adversity Quotient (AQ), juga dikenal sebagai ilmu ketahanan, mencoba mengukur kemampuan seseorang untuk menangani kesulitan dalam hidup [8]. Hidayah dkk menyatakan bahwa Adversity Quotient (AQ) adalah kecerdasan dalam pengolahan kesulitan dan mengubahnya menjadi sebuah tantangan baru untuk dipelajari dan diselesaikan [3]. Paul mengelompokan empat dimensi AQ bernama CO2RE, yaitu Control, Origin, Ownership, Reach, Endurance [9]. Berdasarkan uraian yang telah dipaparkan, dapat diperoleh simpulan bahwa AQ adalah suatu kecerdasan yang harus dimiliki seseorang untuk mengenali kesulitan diri dan mengolahnya menjadi potensi untuk menjadi tantangan yang bisa dihadapi. Adversity Quotient ini merupakan faktor dari segi psikis dan emosi yang sangat penting dan harus diperkuat untuk dimiliki peserta didik selain kemampuan intelektual matematis dalam kegiatan pembelajaran.

Pada masa pandemi covid ini Adversity Quotient penting dimiliki peserta didik, UNESCO menunjukkan bahwa di bulan April sebesar 92\% peserta didik di dunia terkena dampak pada Pendidikan dan kehidupannya [10]. Berdasarkan pernyataan tersebut hampir sebagian besar pelajar terkena dampaknya dari segi kehidupan sosial dan pendidikan. Salah satu dampak besar dari kondisi pandemik saat ini yaitu penutupan sekolah dari semua jenjang yang mempengaruhi banyak peserta 
didik dalam dalam kegiatan pembelajaran. Upaya pemerintah untuk mengurangi komunikasi fisik dalam pembelajaran menghimbau lembaga Pendidikan membuat kondisi kegiatan pembelajaran perlu beralih ke pembelajaran jarak jauh pada periode ini. AQ harus ditingkatkan dari waktu ke waktu dalam proses perubahan kesulitan menjadi kehidupan yang menantang [9].

Penelitian terbaru yang telah dilakukan [1] terdapat hubungan positif yang antara AQ dengan kemampuan berpikir kritis pada peserta didik kelas 12 MIPA. Hal ini selaras dengan sebuah penelitian yang telah dilakukan oleh Amin \& Khabibah [11] menemukan adanya relasi dalam pemecahan masalah matematis apabila ditinjau dari Adversity Quotient dan gaya belajar visual. Berdasarkan hasil penelitian tersebut dan kondisi empiris yang terjadi pada saat ini, peneliti bertujuan untuk mengetahui hubungan Adversity Question dan hasil belajar matematika peserta didik dalam pembelajaran jarak jauh di SMP.

\section{Methodologi}

\subsection{Desain Penelitian}

Pendekatan penelitian yang digunakan adalah penelitian kuantitatif melalui metode survey dengan analisis deskriptif korelasional. Terdapat dua variabel pada penelitian ini, yaitu Adversity Quotient (Variabel X) dan hasil belajar matematika (Y).

\subsection{Responden}

Penelitian ini adalah peserta didik kelas 7 di salah satu SMP swasta di Depok tahun pelajaran 2020/2021 sebanyak 130 peserta didik, dengan jumlah laki-laki sebanyak 61 orang atau 46,9\% dan perempuan sebanyak 69 orang atau $53,1 \%$.

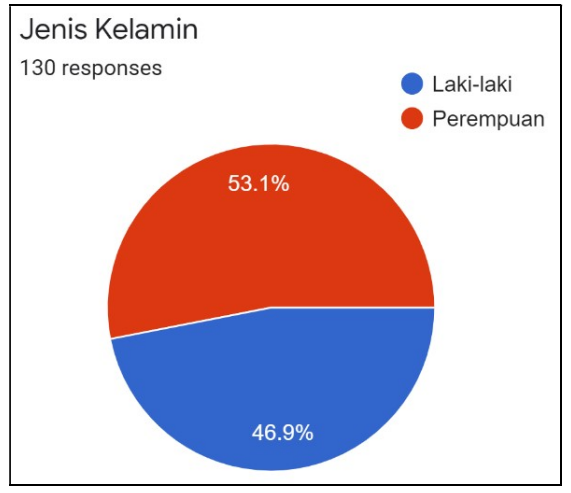

Gambar 1. Demografi Subjek berdasarkan Gender

\subsection{Instrumen Penelitian}

Pengumpulan data dilakukan dengan menggunakan instrumen berupa survey untuk mengumpulkan data AQ peserta didik, sementara untuk hasil belajar matematika dengan teknik dokumentasi dengan melihat nilai ujian peserta didik pada semester ganjil tahun pelajaran 2020/2021. Survey yang digunakan dalam penelitian ini merupakan adaptasi dari Hidayat dengan indikator Control, Origin and Ownership, Reach and Endurance. Masing-masing indikator terdiri dari 4 pernyataan. Skala yang digunakan adalah skala likert dengan memberikan 5 pilihan jawaban yaitu Sangat Setuju, Setuju, Netral, Tidak Setuju dan Sangat Tidak Setuju. Untuk penskoran skala kategori likert, jawaban diberi bobot dengan bobot 5, 4, 3, 2, 1 untuk pernyataan positif sedangkan untuk pernyataan negatif berbobot $1,2,3,4,5$.

\subsection{Analisis Statisitik}

Teknik analisis data yang digunakan dalam penelitian ini adalah uji normalitas, analisis korelasi dan analisis regresi. Uji keofisien korelasi digunakan untuk menentukan keeratan hubungan dua variabel yang diteliti. Sedangkan analisis regresi digunakan untuk mengetahui hubungan Y terhadap nilai X. 


\section{Hasil}

Berdasarkan hasil angket yang terkumpul, diperoleh persentase rata-rata tiap indikator Adversity Quotient peserta didik seperti yang ditunjukkan pada Tabel 1.

Tabel 1. Persentase Rata-Rata Indikator Adversity Quotient setiap Indikator

\begin{tabular}{l|l|l}
\hline No & Indikator & Persentase Rata-Rata \\
\hline 1 & Control & $78,31 \%$ \\
\hline 2 & Origin and ownership & $78,19 \%$ \\
\hline 3 & Reach & $81,46 \%$ \\
\hline 4 & Endurance & $77,96 \%$ \\
\hline
\end{tabular}

Berdasarkan Tabel 1, persentase dari indikator Control sebesar 78,31\%, Origin and ownership sebesar 78,19\%, Reach 81,46\% dan Endurance 77,96\%. Hal ini menunjukkan Adversity Quotient setiap indikator yang dimiliki peserta didik tergolong sedang dan cenderung tidak jauh berbeda di setiap indikator.

Tabel 2. Rekapitulasi Rata-rata Indikator Adversity Quotient berdasarkan Gender

\begin{tabular}{|c|c|c|c|}
\hline \multicolumn{2}{|r|}{ Jenis Kelamin } & Laki-laki & Perempuan \\
\hline \multicolumn{2}{|r|}{ Jumlah peserta didik } & 61 & 69 \\
\hline \multicolumn{4}{|c|}{ Indikator } \\
\hline 1 & Control & 3,95 & 3,88 \\
\hline 2 & Origin dan Ownership & 3,87 & 3,94 \\
\hline 3 & Reach & 4,04 & 4,11 \\
\hline 4 & Endurance & 3,96 & 3,84 \\
\hline \multicolumn{2}{|r|}{ Rata-rata } & 3,95 & 3,94 \\
\hline \multicolumn{2}{|r|}{ Persentase } & $79 \%$ & $79 \%$ \\
\hline
\end{tabular}

Berdasarkan Tabel 2, persentase Adversity Quotient untuk peserta didik laki-laki dan perempuan sebesar 79\%. Hal ini berarti gender tidak berpengaruh terhadap perbedaan Adversity Quotient yang dimiliki peserta didik.

Hasil uji normalitas Adversity Quotient dan hasil belajar menggunakan SPSS versi 25 terdapat dalam Tabel 3.

Tabel 3. Hasil Uji Normalitas Adversity Quotient dan Hasil Belajar One-Sample Kolmogorov-Smirnov Test

Unstandardized

Residual

\begin{tabular}{llr}
\hline $\mathrm{N}$ & & \\
\hline Normal Parameters & & \\
& Mean & .0000000 \\
\cline { 2 - 3 } Most Extreme Differences & Std. Deviation & 3.33544760 \\
\cline { 2 - 3 } & Absolute & .092 \\
\cline { 2 - 3 } & Positive & .066 \\
\cline { 2 - 3 } & Negative &. .092 \\
\hline Test Statistic & & .909 \\
\hline Asymp. Sig. (2-tailed) & & .092 \\
\hline
\end{tabular}

a. Test distribution is Normal.

b. Calculated from data.

c. Lilliefors Significance Correction. 
Tabel 3 menunjukkan bahwa nilai signifikasi 0,92 lebih besar dari 0,05 hal ini menunjukkan bahwa data Adversity Quotient dan hasil belajar peserta didik memiliki sebaran yang normal.

Tabel 4. Uji Korelasi Adversity Quotient dan Hasil Belajar pada Peserta didik Laki-laki

\section{Correlations}

\begin{tabular}{|c|c|c|c|}
\hline & & $\begin{array}{l}\text { Adversity Quotient } \\
\text { (Laki-laki) }\end{array}$ & $\begin{array}{l}\text { Hasil Belajar } \\
\text { (Laki-Laki) }\end{array}$ \\
\hline \multicolumn{2}{|c|}{ Adversity Quotient Pearson Correlation } & 1 & $.998^{* *}$ \\
\hline \multirow{2}{*}{ (Laki-laki) } & Sig. (2-tailed) & & .000 \\
\hline & $\mathrm{N}$ & 61 & 61 \\
\hline \multirow{3}{*}{$\begin{array}{l}\text { Hasil Belajar } \\
\text { (Laki-laki) }\end{array}$} & Pearson Correlation & $.998^{* *}$ & 1 \\
\hline & Sig. (2-tailed) & .000 & \\
\hline & $\mathrm{N}$ & 61 & 61 \\
\hline
\end{tabular}

**. Correlation is significant at the 0.01 level (2-tailed).

Tabel 4 menunjukkan bahwa hubungan Adversity Quotient dan hasil belajar memiliki nilai signifikansi antara Adversity Quotient sebesar 0,000<0,05. Hal tersebut menunjukkan bahwa ada korelasi yang signifikan antara Adversity Quotient dan hasil belajar pada peserta didik laki-laki.

Tabel 5. Uji Korelasi Adversity Quotient dan Hasil Belajar pada Peserta didik Laki-laki

\section{Correlations}

\begin{tabular}{llr|r} 
& & $\begin{array}{c}\text { Adversity Quotient } \\
\text { (Perempuan) }\end{array}$ & \multicolumn{1}{c}{$\begin{array}{c}\text { Hasil Belajar } \\
\text { (Perempuan) }\end{array}$} \\
\hline $\begin{array}{l}\text { Adversity Quotient } \\
\text { (Perempuan) }\end{array}$ & Pearson Correlation & 1 & $1.000^{* *}$ \\
\cline { 2 - 4 } & Sig. (2-tailed) & 69 & .000 \\
\hline N & Pearson Correlation & $1.000^{* *}$ & 69 \\
\hline $\begin{array}{l}\text { Herempuan) } \\
\text { Peremar }\end{array}$ & Sig. (2-tailed) & .000 & 1 \\
\cline { 2 - 4 } & $\mathrm{N}$ & 69 & 69 \\
\hline
\end{tabular}

**. Correlation is significant at the 0.01 level (2-tailed).

Tabel 5 menunjukkan bahwa hubungan Adversity Quotient dan hasil belajar memiliki nilai signifikansi sebesar $0,000<0,05$. Hal tersebut menunjukkan bahwa ada korelasi yang signifikan antara Adversity Quotient dan hasil belajar pada peserta didik perempuan.

\begin{tabular}{|c|c|c|c|c|c|c|}
\hline & & $\begin{array}{r}\text { Tabel } 6 . \\
\text { C }\end{array}$ & $\begin{array}{l}\text { ji Regresi Li } \\
\text { fficients }^{\mathbf{a}}\end{array}$ & & & \\
\hline & & Unstandardizec & Coefficients & $\begin{array}{c}\text { Standardized } \\
\text { Coefficients }\end{array}$ & & \\
\hline Model & & B & Std. Error & Beta & $\mathrm{t}$ & Sig. \\
\hline & (Constant) & .438 & .316 & & 1.386 & .168 \\
\hline & Adversity Quotient & 1.305 & .005 & .999 & 262.325 & .000 \\
\hline
\end{tabular}

a. Dependent Variable: Hasil Belajar

Tabel 6 menunjukkan bahwa nilai konstan (B) sebesar 0,438 dengan setiap peningkatan Adversity Quotient sebesar 1 satuan, maka hasil belajar akan meningkat sebesar 1,305. Hal ini berarti hasil belajar peserta didik meningkat searah dengan meningkatnya Adversity Quotient. 


\section{Diskusi}

Hasil yang ditunjukan pada indikator Control sebesar 78,31\% artinya peserta didik cukup mampu dalam mengelola rasa minder atas hasil yang belum memuaskan, tegar dalam menghadapi kesulitan belajar, aktif dalam belajar serta selalu berusaha rendah diri dan optimis selama proses pembelajaran. Indikator Origin and ownership yang didapatkan sebesar 78,19\% artinya peserta didik cukup mampu dalam bertanggung jawab atas hasil belajar yang didapatkan serta peduli untuk menyelidiki sejauh mana pencapaian dan kesalahannya. Pada indikator Reach didapatkan hasil 81,46\% yang berari peserta didik cukup tinggi dalam kemampuan optimis atas rintangan yang dihadapi selama proses pembelajaran dan indikator Endurance sebesar 77,96\% artinya peserta didik cukup mampu dalam menghadapi penyebab rendahnya hasil belajar dengan menciptakan ide dalam mengatasi masalah tersebut sampai berhasil menyelesaikannya dengan baik.

Uji korelasi menunjukkan Adversity Quotient (X) dan hasil belajar (Y) mempunyai hubungan dengan signifikasi kuat baik pada peserta didik laki-laki maupun perempuan dilihat dari nilai signifikasi $0,00<0,05$. Adversity Quotient memberikan pengaruh yang positif dan searah, diperinci berdasarkan uji regresi yang menunjukkan setiap kenaikan Adversity Quotient sebesar satu satuan akan meningkatkan hasil belajar matematika sebesar 1,305. Hal ini selaras dengan penelitian yang dilakukan oleh Hakim \& Murtafiah [12] yang menunjukkan bahwa resiliensi dan Adversity Quotient mempengaruhi secara positif terhadap kemampuan pemecahan masalah peserta didik. Hubungan yang positif ini mengarahkan bahwa Adversity Quotient harus ditingkatkan untuk meningkatkan hasil belajar peserta didik.

Berdasarkan hasil dari hubungan Adversity Quotient dan hasil belajar tidak dipengaruhi oleh gender, ditunjukkan dari hasil persentasi rata-rata indikator Adversity Quotient yang dimiliki peserta didik laki-laki dan perempuan cukup tinggi dan sama besarnya yaitu $79 \%$. Hal ini sejalan dengan penelitian yang dilakukan oleh Wahidah yang mengungkapkan bahwa gender tidak berpengaruh secara signifikan dalam pembelajaran matematika [13]. Banyak faktor lain yang mempengaruhi hasil belajar peserta didik. Menurut Indriani, guru juga punya peran yang sangat penting dalam peningkatan hasil belajar, faktor lain yang dapat mempengaruhi hasil belajar peserta didik misalnya metode pembelajaran, motivasi belajar, aktivitas belajar, kemampuan awal peserta didik yang berbeda, tingkat kecerdasan dan lain sebagainya [14]. Muhibbin menyebutkan faktor lain yang dapat mempengaruhi hasil belajar peserta didik yaitu faktor internal yaitu aspek fisiologis dan psikologis dan faktor eksternal berupa kondisi lingkungan disekitar siswa [15].

\section{Kesimpulan}

Hasil penelitian menunjukkan Adversity Quotient dan hasil belajar peserta didik kelas 7 di SMP Swasta di Depok menunjukkan hubungan yang positif dan searah dengan hasil persentase di setiap indikator yaitu Control, Origin and ownership, Reach and Endurance cukup tinggi. Rata-rata persentase setiap indikator berdasarkan gender tidak menunjukkan perbedaan dengan hasil masingmasing $79 \%$. Faktor lain yang mempengaruhi hasil belajar matematika siswa disebabkan oleh aspek fisiologis, psikologis dan lingkungan peserta didik.

\section{Daftar Pustaka}

[1] F. A. Nita Rahayu, "Kemampuan Berpikir Kritis Matematis Ditinjau dari Adversity Quotient," Journal Pendidikan, Jurnal Prima, vol. 4, no. 2, 2020.

[2] M. Effendi, "Correlation between Adversity Quotient (AQ) with IQ, EQ and SQ among Polytechnic Students Using Rasch Model," Indian Journal of Science and Technology, vol. 9, no. 1, pp. 1-8, 2016. doi: 10.17485/ijst/2016/v9i47/108695.

[3] S. R. Hidayah, D. Trapsilasiwi, and S. Setiawani, "Proses Berpikir Kritis Siswa Kelas VII F Mts. Al-Qodiri 1 Jember dalam Pemecahan Masalah Matematika Pokok Bahasan Segitiga dan Segi Empat ditinjau dari Adversity Quotient," Jurnal Edukasi, vol. 3, no. 3, 2016. doi: 10.19184/jukasi.v3i3.3517.

[4] M. G. Erikson, and M. Erikson, "Learning outcomes and critical thinking-good intentions in conflict", Studies in Higher Education, vol. 44, no. 12, pp. 2293-2303, 2019. doi: 10.1080/03075079.2018.1486813. 
[5] S. D. Carter, "Comparison of Student Learning Outcomes Assessment Practices Used Globally," Athens Journal of Education, vol. 2, no. 3, pp. 179-192, 2015. doi: 10.30958/aje.23-1.

[6] Y. S. Nasution, and E. Surya, "Application of TPS Type Cooperative Learning in Improving Students' Mathematics Learning Outcomes," International Journal of Sciences: Basic and Applied Research (IJSBAR), vol. 34, no. 1, pp. 116-125, 2017.

[7] L. Qin, Y. Zhou, and W. T. Tanu, "The Analysis of Mathematics Adversity Quotient of Left Behind Junior High School Students in Rural Areas. Open Journal of Social Sciences, vol. 07, no. 10, pp. 331-342, 2019. doi: 10.4236/jss.2019.710028,

[8] S. Singh, and T. Sharma, "Affect of Adversity Quotient on the Occupational Stress of IT Managers in India," Procedia Computer Science, vol. 122, no. 86-93, 2017. doi: 10.1016/j. procs.2017.11.345,

[9] C. W. Wolor, A. Pratama, S. Aditya, F. Nadya Fadillah, and D. Purwana, "Adversity quotient in improving millennial generation salespeople's performance in the industrial revolution 4.0," Humanities and Social Sciences Reviews, vol. 8, no. 1, pp. 220-226, 2020. doi: 10.18510/ hssr.2020.8131.

[10] M. T. Hebebci, Y. Bertiz, and S. Alan, "Investigation of Views of Students and Teachers on Distance Education Practices during the Coronavirus (COVID-19) Pandemic," International Journal of Technology in Education and Science, vol. 4, no. 4, pp. 267-282, 2020. doi: 10.463 28/ijtes.v4i4.113.

[11] D. M. Amin, and M. Khabibah, "Relational thinking in problem solving mathematics based on adversity quotient and visual learning style," International Journal of Trends in Mathematics Education Research, vol. 2, no. 4, pp. 161-164, 2019.

[12] F. Hakim, and M. Murtafiah, "Adversity Quotient and Resilience in Mathematical Proof Problem-Solving Ability," MaPan, vol. 8, no. 1, pp. 87, 2020. doi: 10.24252/mapan.2020 v8n1a7.

[13] W. Fitriani, "Analisis Self Efficacy dan Hasil Belajar Matematika Siswa di MAN 2 Batusangkar," Jurnal Pendidikan, vol. 1, 141-158, 2017.

[14] S. Suharti, A. Muslim, S. Sriyanto, "Hubungan Motivasi Belajar dengan Prestasi Belajar Matematika Siswa Kelas V SD Negeri Daerah Binaan 1 Sumbang Banyumas," MADRASAH Jurnal Pendidikan dan Pembelajaran Dasar, vol. 51, pp. 51-64, 2020.

[15] A. Muhammad, A. Azis, and R. Ngitung, "Hubungan Kecerdasan Naturalistik, Kecerdasan Interpersonal dan Kecerdasan Intrapersonal dengan Hasil Belajar Biologi Siswa Kelas XI IPA SMA Negeri di Kota Makassar," UNM Journal of Biological Education, vol. 2, 2018. 